\title{
Memantine Hydrochloride
}

National Cancer Institute

\section{Source}

National Cancer Institute. Memantine Hydrochloride. NCI Thesaurus. Code C47601.

The hydrochloride salt of memantine, a low-affinity, voltage-dependent, noncompetitive $\mathrm{N}$-methyl-D-aspartate (NMDA) receptor antagonist. Memantine binds to and inhibits cation channels of glutamanergic NMDA receptors located in the central nervous system (CNS), preventing the prolonged influx of calcium ions and the associated neuronal excitotoxicity, and thereby potentially enhancing cognitive function. Memantine is also a 5-hydroxytryptamine type 3 (5HT3) receptor and nicotinic receptor antagonist. 